\title{
MAQASHID SYARI'AH SEBAGAI EPISTEMOLOGI PENDIDIKAN PANCASILA
}

\author{
Ahmad Fahri Yahya Ainuri \\ Pascasarjana UIN Walisongo Semarang \\ E-mail: fahriyahya03@gmail.com
}

\begin{abstract}
As Indonesian people, of course we are familiar with religious groups with transnational ideologies that are oriented towards replacing government systems with Islamic systems (Imamat / Khilafah) based on the Qur'an and Hadith. Actually there is nothing wrong with the group's vision because the khilahfah system is a product of ijtihad of the predecessor ulama and normatively does not contradict Islamic law. It's just that the effort to coerce to change the law which has become a collective agreement in a country can legally be said as an act of rebellion and the act is not constitutionally justified. To address this phenomenon, the writer wants to give an understanding that implicitly our country (Indonesia) has actually implemented laws that are in accordance with Islamic sharia because the Pancasila ideology which is used as a national and state paradigm is fully in line with the sharia maqashid as contained in the Koran 'and Hadith which fully aims to educate people to become human beings who are deified, humane, united, just manifested into a common life (social life).
\end{abstract}

Keywords: Islamic maqashid, Epistemology, Pancasila Education.

\begin{abstract}
Abstrak
Sebagai masyarakat Indonesia, tentu kita tidak asing dengan adanya kelompok beragama dengan ideologi transnasional yang berorientasi mengganti sistem pemerintahan dengan sistem Islam (Imamah/Khilafah) yang berlandaskan al-Qur'an dan Hadis. Sebenarnya tidak ada yang salah dengan visi kelompok tersebut karena sistem khilahfah merupakan produk ijtihad para ulama pendahulu dan secara normatif tidak bertentangan dengan syariat Islam. Hanya saja, usaha melakukan paksaan untuk merubah undangundang yang sudah menjadi kesepakatan bersama dalam suatu negara secara yuridis bisa dikatakan sebagai tindakan pemberontakan dan tindakan tersebut tidak dibenarkan secara konstitusional. Untuk mensikapi fenomena tersebut penulis ingin memberikan pemahaman bahwa secara implisit negara kita (Indonesia) sebenarnya sudah menerapkan undang-undang yang sesuai dengan syari'at Islam karena ideologi pancasila yang dijadikan sebagai paradigma berbangsa dan bernegara sepenuhnya sejalan dengan maqashid
\end{abstract}


syariah yang tertuang dalam al-Qur'an dan Hadis yang spenuhnya bertujuan untuk mendidik masyarakat menjadi manusia yang berketuhanan, berperikemanusiaan, bersatu, adil yang termanifestasi ke dalam kehidupan bersama (kehidupan sosial).

Kata Kunci : maqashid syariah, Epistemologi, Pendidikan Pancasila.

\section{A. LATAR BELAKANG}

Al-Qur'an mengandung konsep hukum yang unik. Sebagai hukum Allah, konsep hukum dalam al-Qur'an tentunya memiliki karakteristik yang ideal dalam mewujudkan kemaslahatan bagi umat manusia. Demikian Hadis sebagai bayan (penjelas) terhadap al-Qur'an yang juga mengandung aturan-aturan hukum syariah yang pada dasarnya sama mengarah kepada realisasi kehidupan manusia di dunia supaya selamat dikehidupan akhirat nanti. Dari situ menjadi sebuah keniscayaan bagi umat Islam yang Iman kepada Allah dan Rasul-nya untuk senantiasa taat dan selalu berpegang teguh kepada seperangkat norma yang sudah tersusun sempurna di dalam al-Qur'an tersebut.

Kemudian, melihat lebih jauh fenomena yang terjadi di negara kita (Indonesia) dimana adanya sementara kelompok yang mempermasalahkan pancasila sebagai paradigma bermasyarakat, berbangsa dan bernegara. Mereka menilai bahwa pancasila adalah sistem jahiliyah yang tidak layak untuk dijadikan acuan dalam kehidupan bermasyarakat bahkan bernegara. Untuk itu pancasila harus diganti dengan al-Qur'an yang notabenenya diyakini secara bersama sebagai sumber hukum primer dalam Islam. Sudut pandang yang demikian ini jika tidak segera disikapi secara arif dan bijak maka bisa membawa masyarakat ke dalam kekacauan berfikir yang sangat berpotensi menimbulkan perpecahan. Berbagai ketegangan antar elemen masyarakat akan sangat mungkin terjadi ketika negara hanya diberlakukan sistem hukum dari agama tertentu, melihat Indonesia yang 
sejatinya lahir dan tumbuh di atas semangat keberagaman Suku, Agama, Ras dan Antar golongan.

Oleh karena itu, untuk menjawab pertanyaan sekaligus meredam kemungkinan adanya ketegangan di atas, pada makalah ini akan penulis paparkan secara mendalam beberapa tujuan syar'i menurunkan syariat Islam (maqashid syari'ah) dengan melihat bagaimana tujuan syar'i tersebut diimplementasikan kepada manusia, serta mengkaji relevansinya dengan Pancasila sebagai dasar Ideologi Negara Kesatuan Republik Indonesia, sehingga akan diperoleh pemahaman terkait tepat atau tidaknya pancasila dijadikan acuan dalam kehidupan bermasyarakat bahkan bernegara serta perlu atau tidaknya pancasila digantikan dengan al-Qur'an dan sumber hukum Islam lainnya.

\section{B. PEMBAHASAN}

\section{Beberapa tujuan syar'i menurunkan syariat Islam}

\section{a) Pengertian Tujuan Syar'i}

Al-Qur'an ${ }^{1}$ selaku sumber ajaran ${ }^{2}$, tidak memuat aturan-aturan yang terperinci tentang ibadah dan muamalah. Buktinya, hanya

1 Al-Qur'an diturunkan oleh Allah swt. kepada Nabi Muhammad saw. adalah dengan perantara Malaikat Jibril (Ruh Al-Amien) dan caranya tidak sekali turun, tetapi berangsur-angsur, dari se-ayat dua ayat dan tempo-tempo sampai sepuluh ayat. Bahkan kadang-kadang diturunkan hanya tiga perkataan, kadang-kadang hanya setengah ayat dan demikianlah selanjutnya, menurut kepentingannya sebagaimana yang dikehendaki oleh Allah swt. Munawar Khalil, Al-Qur'an dari Masa ke Masa, (Semarang: Ramadhani, 2010), 2 .

${ }^{2}$ Sebagai sumber utama ajaran Islam, ada ulama yang membagi kandungan alQur'an dalam tiga kelompok besar, yakni: aqidah, khuluqiyyah, dan amaliyah. Aqidah berkaitan dengan dasar-dasar keimanan. Khuluqiyyah berkaitan dengan etika atau akhlak. Sedangkan amaliyah berkaitan dengan aspek-aspek hukum yang timbul dari ungkapanungkapan (aqwảl) dan perbuatan-perbuatan (af'al) manusia. Kelompok ketiga ini, dalam sistematika hukum Islam dibagi dalam dua bagian besar, yaitu (1) ibadah, yang di dalamnya diatur pola hubungan manusia dengan Tuhan, dan (2) muamalah yang di dalamnya diatur pola hubungan antara sesama manusia. Abdul Wahab Khalaf, Ilmu Ushul Fiqih, Cet. 12. (Khairo: Daar Al-Qalam, 1978), 32. 
terdapat 368 ayat yang berkaitan dengan aspek-aspek hukum. ${ }^{3}$ Hal ini berarti, bahwa sebagian masalah-masalah hukum dalam Islam, oleh Tuhan hanya diberikan dasar-dasar atau prinsip-prinsipnya saja dalam al-Qur'an. Dasar-daar atau prinsip-prinsip ini, dijelaskan lebih lanjut oleh Nabi saw melalui hadis-hadisnya. Bertolak dari dua sumber inilah kemudian, aspek-aspek hukum terutama bidang muamalah dikembangkan dengan mengaitkannya dengan tujuan syar'i atau maqasid al-syari'ah.

Secara etimologi, Tujuan Syar'i atau yang disebut مقاصد الثريعة (Maqashid al-syari'ah) di atas merupakan istilah gabungan dua kata: مقاصد (maqashid) dan الثريعة (al-syari'ah). Maqashid adalah bentuk plural dari مقصد (maqshad), yang merupakan derivasi dari kata kerja قصد , يقصد (qashada, yaqshudu) dengan beragam makna, seperti menuju suatu arah, tujuan, tengah-tengah, adil dan tidak melampui batas. ${ }^{4}$ Sementara itu syariah secara etimologi bermakna jalan menuju mata air, dalam terminologi fiqih sebagaimana Muhammad Syah mengutip pendapat Dr, Farouk Abu Zaid berarti hukum-hukum yang disyariatkan oleh Allah untuk hamba-Nya baik yang ditetapkan melalui al-Qur'an maupun sunnah Nabi Muhammad yang berupa perkataan-perbuatan, atau ketetapan Nabi yang menyangkut kehidupan dunia dan akhirat. ${ }^{5}$

Sedangkan secara terminologis, dalam periode-periode awal, syari'ah merupakan al-nusus al-muqaddasah, dari al-Qur'an dan hadis yang mutawatir yang sama sekali belum dicampuri oleh

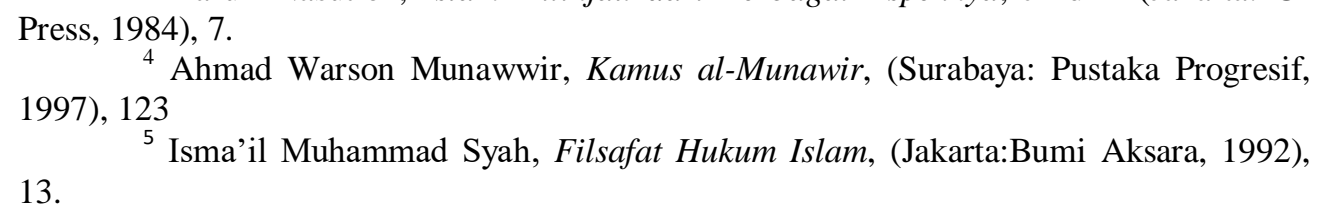
1997), 123

${ }^{4}$ Ahmad Warson Munawwir, Kamus al-Munawir, (Surabaya: Pustaka Progresif,

${ }^{5}$ Isma'il Muhammad Syah, Filsafat Hukum Islam, (Jakarta:Bumi Aksara, 1992), 13.

${ }^{3}$ Harun Nasution, Islam Ditinjau dari Berbagai Aspeknya, Jilid II (Jakarta: UI 
pemikiran manusia. Dalam wujud seperti ini syari'ah disebut altariqah al-mustaqimah. ${ }^{6}$ Muatan syari'ah dalam arti ini mencakup 'amaliyah, khuluqiyah. Dalam perkembangan sekarang terjadi reduksi muatan arti syariah, dimana aqidah tidak masuk lagi dalam pengertian syariah. ${ }^{7}$ Al-Syatibi melaporkan hasil penelitian para ulama terhadap ayat-ayat al-Qur'an dan hadis, bahwa hukum-hukum disyariatkan Allah untuk mewujudkan kemaslahatan umat manusia, baik di dunia maupun di akhirat. ${ }^{8}$ Dengan demikian, mustahil Tuhan menurunkan hukum (Syariah) tanpa tujuan tertentu, dan tujuan tersebut tidak lain adalah untuk merealisasikan kehidupan manusia di dunia guna membekali diri untuk kehidupan yang lebih kekal, yakni di akhirat nanti.

\section{b) Sejarah Tujuan Syar'i}

Sebagai tema tersendiri dalam syariah, maqashid tidak mendapat banyak perhatian pada masa-masa awal perkembangan pemikiran hukum Islam. Karena itu dapat dikatakan maqasid merupakan pengayaan akhir khazanah fiqih madzhab-madzhab utama. ${ }^{9}$ Secara umum dapat dikatakan bahwa pemikir hukum Islam Menyibukkan diri dengan keadaan literal teks suci, dan teori hukum ushul telah berperan besar memajukan tujuan tersebut. Kecendrungan pemikiran yurisdik yang literalis seperti ini umumnya lebih kentara di kalangan tradisionalis para ahli hadis dibandingkan dengan kalangan rasionalis para ahl al-ray, maka dari itu kaum tradisionalis cenderung memandang syariah sebagai seperangkat aturan, perintah dan

\footnotetext{
${ }^{6}$ Fazlurrahman, Islam, terj. oleh Ahsin Muhammad (Bandung: Pustaka, 1984), 14.

${ }^{7}$ Asafri Jaya Bakri, Konsep Maqashid Syari'ah Menurut al-Syatibi, Cet. I, (Jakarta: PT Raja Grafindo Persada, 1996), 61-62.

${ }^{8}$ Al-Syatibi, al-Muwafaqat fi ushul al ahkam, Jilid I, (Mesir: Daar Al Fikr), 3.

${ }^{9}$ M. Hashim Kamali, Membumikan Syariah, Terj. Shariah Law, (Jakarta: Mizan Publika, 2008), 164.
} 
larangan yang ditujukan kepada individu yang kompeten (mukallaf), dan para rasionalis diharapkan untuk mentaati arahannya. Tradisi tekstualis selama tiga abad setelah tahun awal Islam Tidak banyak memberi perhatian pada maqashid. Baru pada Al-Gazali (w 1111), kemudian Al-Syatibi (w 1388), terjadi perkembangan yang berarti dalam perumusan teori maqashid. ${ }^{10}$

Singkatnya, istilah maqashid baru mulai digunakan pada abad kesepuluh dalam tulisan hukum Abu Abdullah Al-Tirmidh al Hakim (w.932) dan rujukan lainnya muncul berulang kali dalam karya Haramayn Al Juwaini ${ }^{11}$ (w. 1085). Gagasan-gagasan Juwayni kemudian dikembangkan lebih lanjut oleh muridnya, Abi Hamid AlGhazali yang banyak menulis tentang kepentingan publik (mashlahah) dan rasional dalam karyanya Shifa Al-Ghalil dan AlMusthafa. Imam Al Ghazali secara umum bersifat mengkritisi. ${ }^{12}$

Beberapa penulis ternama yang terus memberikan kontribusi pada maqashid, walau barangkali tidak semuanya konsisten, kontribusi mereka bisa dikatakan penting bagi perkembangan berbagai pemikiran. Diantaranya, Fakhr Al- Din Razi (1208) dan Sayf din Al-Amid (w. 1233) mengidentifikasi maqashid sebagai kriteria pilihan di antara berbagai analogi yang saling bertentangan, dan merinci tata urutan prioritas internal diantara berbagai kelas maqashid. Fuqaha Maliki, Syihab Al-Din Al-Qarafi (1285), menambah kualifikasi yang keenam ke dalam daftar tersebut yakni

\footnotetext{
${ }^{10}$ M. Hashim Kamali, Membumikan Syariah, Terj. Shariah Law, 165.

${ }^{11}$ Al Juwaini, mungkin merupakan orang pertama yang mengklasifikasi maqasid menjadi tiga kategori, yakni esensial, komplementer dan yang diiginkan (dharuriyat, hajiyat, tahsiniyat). M. Hashim Kamali, Membumikan Syariah, Terj. Shariah Law, 166.

12 Terkait maqasid iu sendiri Al-Ghazali menulis secara tegas bahwa syariah hendak mencapai lima tujuan, yakni yang terkait keimanan, kehidupan, intelek, keturunan, dan kepemilikan yang harus dilindungi sebagai perioritas yang absolut. M. Hashim Kamali, Membumikan Syariah, Terj. Shariah Law, 166.
} 
perlindungan atas kehormatan. Qardhawi lebih jauh lagi memperpanjang daftar maqasid untuk mencakup bantuan kesejahteraan sosial. ${ }^{13} \mathrm{Jadi}$, bisa dikatakan berbagai pola pemikiran ulama terkait maqashid memiliki basis yang sama yakni berbicara tentang kemaslahatan. Karena beberapa dari mereka hanya bersifat mengkritis serta menambahkan gagasan ke dalam kualifikasi maqashid yang dirumuskan oleh ulama sebelumnya.

Abdul Wahhab Khallaf menguatkan bahwa nash-nash syari'ah tidak dapat dipahami secara benar kecuali oleh seseorang yang mengetahui maqashid al-syari'ah (tujuan hukum). ${ }^{14}$ Pendapat ini sejalan dengan pandangan pakar fiqh lainnya yaitu Wahbah alZuhaili, yang menyatakan bahwa pengetahuan tentang maqashid alsyari'ah merupakan persoalan dharuri (urgen) bagi mujtahid ketika akan memahami nash dan membuat istinbath hukum, dan bagi orang lain dalam rangka mengetahui rahasia-rahasia syari'ah. ${ }^{15}$

\section{c) Pembagian Tujuan Syar'i}

Bila diteliti semua perintah dan larangan Allah, baik dalam alQur'an maupun hadis yang dirumuskan dalam fiqh (hukum Islam), akan terlihat bahwa semuanya mempunyai tujuan tertentu dan tidak ada yang sia-sia. Semuanya mengandung hikmah yang mendalam, yaitu sebagai rahmat bagi umat manusia. Sebagaimana ditegaskan dalam QS. al-Anbiya ayat 107 :

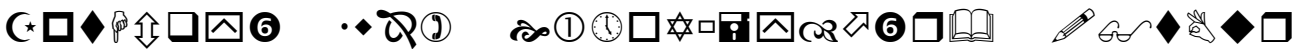 解约全}

${ }^{13}$ M. Hashim Kamali, Membumikan Syariah, Terj. Shariah Law, 166.

${ }^{14}$ Abd al-Wahhab Khallaf, Ilmu al-Ushul al-Fiqh, (Kairo: Maktabah al-Dakwah alIslamiyah, 1968), hlm. 198.

${ }^{15}$ Wahbah al-Zuhaili, Ushulal-Fiqh al-Islami, hlm. 1017 
"Dan Kami tidak mengutus engkau (Muhammad), melainkan untuk (menjadi) rahmat bagi semesta alam."

Ungkapan 'rahmat bagi seluruh alam' dalam ayat di atas diartikan dengan kemasalahatan umat. Dalam kaitan ini para ulama sepakat, bahwa memang hukum syara' itu mengandung kemaslahatan untuk umat manusia. ${ }^{17}$ Abul Qasim At-Tabrani telah meriwayatkannya dari Abdan ibnu Ahmad, dari Isa ibnu Yunus ArRamli, dari Ayyub ibnu Suwaid, dari Al-Mas'udi, dari Habib ibnu Abu Sabit, dari Sa'id ibnu Jubair, dari Ibnu Abbas sehubungan dengan makna firman-Nya: Dan tiadalah Kami mengutus kamu melainkan untuk (menjadi) rahmat bagi semesta alam. (Al-Anbiya: 107) Ibnu Abbas mengatakan bahwa orang-orang yang mengikutinya beroleh rahmat di dunia ini dan di akhirat kelak. Sedangkan orangorang yang tidak mengikutinya dapat terhindar dari cobaan berupa ditenggelamkan ke bumi, dikutuk, dan ditimpa azab yang pernah dialami oleh umat-umat lain sebelum mereka. ${ }^{18}$

Kemaslahatan dalam taklif Tuhan dapat berwujud dalam dua bentuk: (1) bentuk hakiki, yaitu manfaat langsung dalam arti kausalitas, dan (2) dalam bentuk majazi, yaitu bentuk yang merupakan sebab yang membawa kepada ke-maslahatan. ${ }^{19}$ Kemaslahatan itu dapat diwujudkan jika tiga tingakatan dapat diwujudkan dan dipelihara. Ketiga tingkatan pokok itu menurut Abdul Wahhab Khallaf adalah, adalah Dharuriyat, Hajiyat dan 2004), 461.

${ }^{16}$ Departemen Agama R.I,al-Qur'an dan Terjemahnya (Jakarta: CV Naladana,

${ }^{17}$ Amir Syarifuddin, Ushul Fiqh, Jilid 2, (Jakarta: PT Logos Wacana Ilmu, 1999), 206.

${ }^{18}$ Imam jalil al-Hafidh Imaduddin Abu Al Fida' Isma'il bin Katsir, Tafsir alQur'anul Karim; Ibnu Katsir, (Mesir, Daar Mesr Ath Tabaah, t.t), 208.

${ }^{19}$ Husein Hamid Hasan, Nazariyah al-Maslahah fi al-Fiqh al-Islảmı̌ (Mesir: Dar al-Nahdah al-'Arabiyyah, 1971), 5. 
Tahsiniyat. ${ }^{20}$ Untuk memudahkan kita dalam memahami maqasid Syariah, penulis membuat skema dari pembagian Maqasid Syariah sebagai berikut:

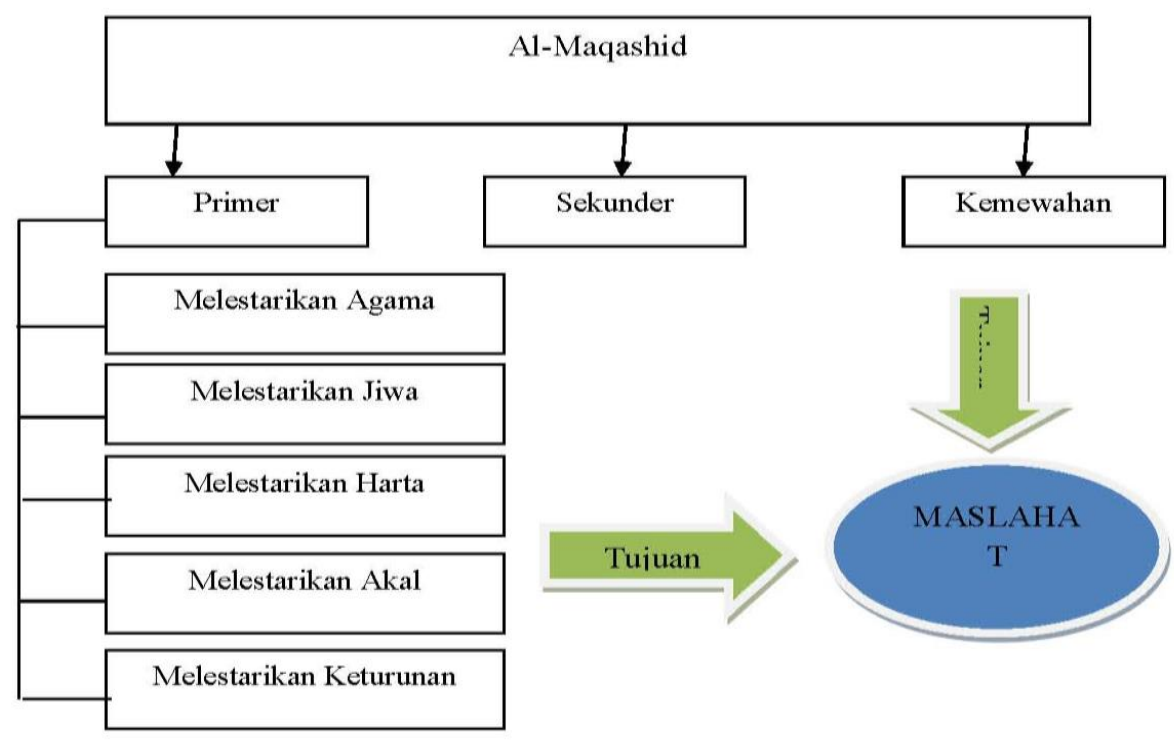

Pertama, Dharuriyat ialah tingkat kebutuhan yang harus ada atau disebut dengan kebutuhan perimer. Jika tingkat kebutuhan ini tidak dipenuhi akan terancam keselamatan umat manusia baik di dunia maupun di akhirat kelak. Menurut Al-Syatibi yang termasuk dalam kategori ini, yaitu memelihara agama, memelihara jiwa, memelihara akal, memelihara kehormatan dan keturunan, serta memelihara harta. ${ }^{21}$

Memelihara agama dalam peringkat dharuriyat, yaitu memelihara dan melaksanakan kewajiban keagamaan yang masuk tingkat primer, seperti Syahadat, melaksanakan shalat lima waktu,

${ }^{20}$ Abdul Wahab Khalaf, Ilmu Ushul Fiqih, 10.

${ }^{21}$ Al-Syatibi, al-Muwafaqat fi ushul al ahkam, Jilid I, ( Mesir: Daar Al Fikr), 4. 
zakat, puasa, dan haji. ${ }^{22}$ Memelihara jiwa dalam tingkat Dharuriyat seperti memenuhi kebutuhan pokok berupa makanan untuk mempertahankan hidup. Memelihara akal dalam peringkat Dharuriyat seperti diharamkanya meminum minuman keras. Memelihara keturunan dalam peringkat dharuriyat seperti disyariatkannya nikah dan dilarang berzina. Memelihara harta dalam peringkat dharuriyat seperti larangan mengambil harta orang lain. ${ }^{23}$

Kedua, Hajiyat ialah kebutuhan sekunder, apabila tidak diwujudkan tidak sampai mengancam keselamatannya. namun akan mengalami kesulitan kesusahan di dalam di dalam hidupnya. ${ }^{24}$ Menurut Abdul Wahab Khallaf keringanan (Rukhsoh) sebagai wujud kepedulian syariat Islam terhadap kebutuhan Umat Manusia. ${ }^{25}$

Ketiga Tahsiniyat ialah tingkat kebutuhan apabila tidak terpenuhi tidak mengancam eksistensi dari lima pokok dharuriyat di atas, dan tidak pula menimbulkan kesulitan. Dengan kata lain kebutuhan ini hanyalah menjadi pelengkap. ${ }^{26}$ Sebagaimana yang dikemukakan oleh Al-Syatibi bahwasanya hal-hal yang merpakan kepatutan menurut adat istiadat kebiasan. Menghindarkan diri dari hal-hal yang tidak enak dipandang oleh mata. Serta sesuai dengan tuntutan norma dan akhlak. ${ }^{27}$

\section{Maqashid Syariah Sebagai Dasar Epistemologi Pendidikan Pancasila}

${ }^{22}$ Mardani, Ushul Fiqh, (Jakarta: Raja Grafindo Persada, 2013), 338.

${ }^{23}$ Abdul Wahab Khalaf, Ilmu Ushul Fiqih, 201.

${ }^{24}$ Satria Effendi, Ushul Fiqih, 235.

${ }^{25}$ Abdul Wahab Khalaf, Ilmu Ushul Fiqih, 202.

${ }^{26}$ Satria Effendi, Ushul Fiqih, 236.

27 Al-Syatibi, al-Muwafaqat fi ushul al ahkam, 5. 
Tanpa bermaksud membidik kelompok tertentu, pastinya sudah sangat familiar ditelinga kita sebagai masyarakat Indonesia tentang adanya sementara kelompok yang menolak Pancasila ${ }^{28}$ sebagai dasar ideologi Negara Kesatuan Republik Indonesia (NKRI). Bahkan ada yang secara vulgar mengatakan bahwa Indonesia menganut sistem Jahiliah, karena tidak menjadikan al-Qur'an dan Hadis sebagai landasan berfikir. Memang tidak bisa dinafikkan tentang adanya gerakan di tengah-tengah masyarakat yang melontarkan wacana mendirikan kembali Khilafah Islamiyah. Agenda yang dicanangkan tidak lain adalah untuk menghidupkan kembali kejayaan Islam dan mengemban dakwah Islam ke seluruh penjuru dunia. Dengan kata lain mengajak kaum muslimin (khususnya di Indonesia) kembali hidup secara Islami dalam daulah Islam, di mana seluruh kegiatan kehidupannya dalam payung aturan Islam yang termaktub dalam Qur'an dan Hadis, bukan berdasarkan Pancasila - yang dipandang - berbenturan dengan nilai-nilai keIslaman.

Dalam sidang PPKI pada tanggal 18 Agustus 1945 dan tercantum dalam pembukaan UUD 1945, Pancasila secara resmi disahkan oleh para pendahulu bangsa sebagai dasar filsafat negara Republik Indonesia, dengan rumusan ; 1). Ketuhanan Yang Maha Esa, 2). Kemanusiaan yang adil dan beradab, 3). Persatuan Indonesia, 4). Kerakyatan yang dipimpin oleh hikmat kebijaksanaan dalam

28 Secara etimologis makna "Pancasila" berasal dari bahasa sansekerta. Kata pancasila memiliki dua macam arti secara leksikal yaitu: "Panca" artinya "Lima", sedangkan "Syila" vokal i pendek artinya "Batu Sendi" atau "Dasar". "Syiila" vokal i panjang artinya "Peraturan tingkah laku yang baik, yang penting atau yang senonoh". Lebih lanjut Lihat, Kaelan, Pendidikan Pancasila, (Yogyakarta: Paradigma, 2010), 21 
permusyawaratan/perwakilan, 5). Keadilan sosial bagi seluruh rakyat Indonesia. ${ }^{29}$

Lebih lanjut untuk memberi pemahaman yang komprehensif selanjutnya akan diberikan analisis bagaimana relevansi Pancasila dengan Maqasid Syariah.

1. Ketuhanan Yang Maha Esa

Sebenarnya sila pertama dalam Pancasila, yakni “Ketuhanan Yang Maha Esa” merupakan revisi dari sila pertama dalam Piagam Jakarta, yang berbunyi "Ketuhanan dengan kewajiban menjalankan syari'at Islam bagi pemelukpemeluknya”. Revisi tersebut dilakukan karena mengingat Negara Indonesia yang dihuni oleh masyarakat dengan latar belakang Agama dan Keyakinan yang berbeda. Oleh sebab itu, dalam sidang PPKI yang mewakili seluruh rakyat Indonesia kemudian diambil suatu konsensus sehingga berakhir pada penetapan bahwa Indonesia merupakan Negara Kesatuan yang dibangun atas keberagaman Agama, Suku, Ras dan Antar golongan.

Melihat rumusan di atas dalam hal ini, Negara sepakat tidak memberikan keistimewaan terhadap masyarakat dengan agama tertentu (Islam), walaupun pada kenyataan agama tersebut menjadi agama mayoritas yang dipeluk oleh masyarakat di Indonesia. Meskipun demikan, untuk sila yang pertama ini secara eksplisit bisa dilihat sangat sejalan dengan syari'at Islama. Karena ditinjau dari pendekatan tekstual (gramatis) bunyi sila pertama ini nampak tegas sekali sesuai dengan inti dari ajaran Islam yang menekankan ke-Tauhidan. Sebagaimana di dalam al-Qur'an, Allah

${ }^{29}$ Kaelan, Pendidikan Pancasila, 26 
menyeru kepada umat manusia untuk kembali kepada konsep Kesatuan, yakni menyembah Tuhan yang Maha Esa.

Allah berfirman dalam Q.S Al-Ikhlas ayat Pertama;

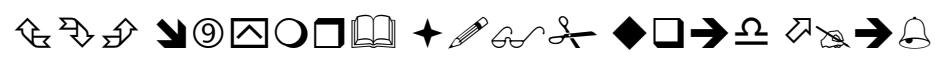

"Katakanlah: "Dia-lah Allah, yang Maha Esa"

Selanjutnya, Q.S Al-Baqarah, ayat 163 :

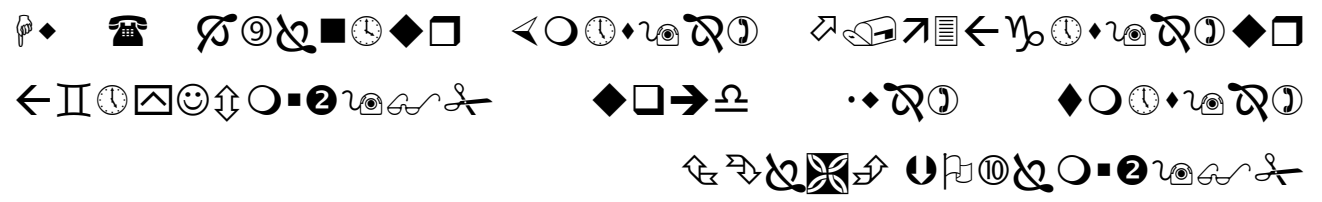

"Dan Tuhanmu adalah Tuhan yang Maha Esa; tidak ada Tuhan melainkan Dia yang Maha Pemurah lagi Maha Penyayang." Juga, Q.S Al-Anbiya, ayat 22 :

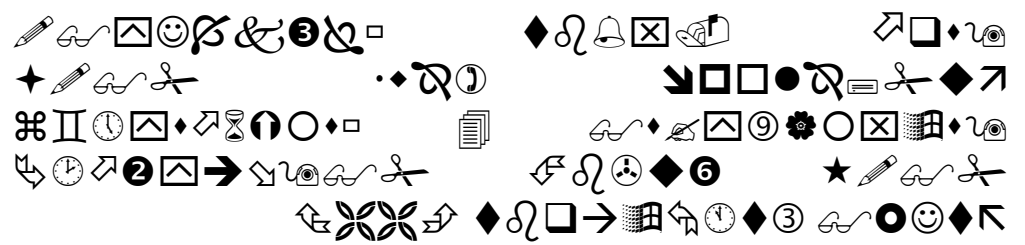

"Sekiranya ada di langit dan di bumi tuhan-tuhan selain Allah, tentulah keduanya itu telah Rusak binasa. Maka Maha suci Allah yang mempunyai 'Arsy daripada apa yang mereka sifatkan"

Kemudian berdasarkan hujjah di atas, maka bisa ditemukan Maqashid Syari'ah dalam sila pertama yang selanjutnya diketahui sebagai dasar paradigma pancasila. Hal tersebut bisa dilihat dari illah dengan melihat produk analisis yang mengajarkan sifat-sifat dan keadaan masyarakat yang harus sesuai atau kembali pada nilanilai Tuhan Yang Maha Esa, yang dalam Iman Islam dikenal sebagai Allah swt.

Keadaan di atas maksudnya, bahwa sila pertama dari pancasila tersebut mengacu pada unsur pokok dalam suatu negara yakni manusia. Karena negara sebagai lembaga hidup bersama 
sebagai lembaga kemanusiaan dan manusia adalah sebagai makhluk ciptaan Tuhan Yang Maha Esa, maka adanya manusia bisa dikatakan sebagai akibat dari adanya Tuhan yang merupakan sang pencipta sebagai akibat dari hukum kausalitas. Tuhan adalah sebagai asal mula segala sesuatu, adanya Tuhan adalah mutlak, sempurna, tak terbatas serta pula sebagai pengatur tata tertib alam. ${ }^{30}$ Oleh karena itu Ketuhanan Yang Maha Esa Sebagai dasar negara, merupakan sumber nilai (Syari' at) yang betasal dari Tuhan yang bila mana diaplikasikan dengan baik maka terbentuklah suatu negara dengan karakter masyarakat yang baik dalam dimensi jasmani maupun rohani.

Sehingga dengan demikian sila pertama bisa dikatakan sangat relevan dengan rumusan Maqashid Syariah yang mengajarkan masyarakat untuk memelihara agama (Hifdz adDin), yang termanifestasikan dalam pengaplikasian nilai-nilai luhur dari Tuhan Yang Maha Esa (Allah) baik dalam dimensi jasmani maupun rohani kepada masyarakat Indonesia. Jika saja tingkat kebutuhan Dharuriyat ini tidak dipenuhi atau tidak ada di dalam rumusan Pancasila, niscaya akan terancam keselamatan umat manusia yang hidup di suatu negara, khususnya di Indonesia baik di dunia maupun di akhirat kelak.

2. Kemanusiaan yang adil dan beradab

Setelah pasal pertama terpenuhi, dan bisa diterapkan dengan baik tanpa adanya kesalah-pahaman, maka akan sangat memungkinkan lahirnya masyarakat Indonesia yang bersatu dan

\footnotetext{
${ }^{30}$ Kaelan, Pendidikan Pancasila, 64.
} 
berdaulat sebagai komponen terpenting dalam suatu negara yang adil dan beradab.

Ini juga berjalan lurus dengan apa yang tertuang di dalam Syariat Islam yang juga sangat menghendaki manusia untuk menjunjung tinggi nilai moral (akhlaq).

Allah berfirman dalam Q.S al-Qalam ayat 4:

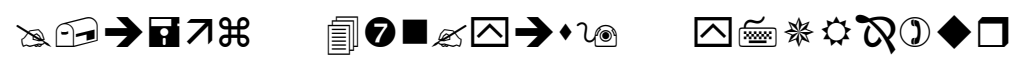

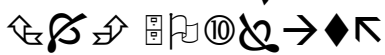
"dan Sesungguhnya kamu (Muhammad saw) benar-benar berbudi pekerti yang agung."

Kemudian diperkuat dengan Hadis yang berbunyi :

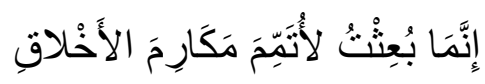

"Sesungguhnya aku diutus untuk menyempurnakan kemuliaan akhlaq" (HR. Al-Bayhaqi dalam bab Syahadat)

Dalil di atas menunjukkan bagaimana (Syariah) Islam datang dengan tujuan utama mengajarkan perilaku yang mulia kepada manusia, agar manusia mampu merealisasikan tugasnya sebagai khalifah di bumi dengan baik dan terhindar dari jeratan degradasi moral yang berpotensi memusnahkan eksistensinya. Cara ini ditempuh dengan mengutus seorang Rasul yang benarbenar memiliki budi pekerti agung sehingga sangat layak untuk dijadikan teladan.

Hal ini sangat mendukung sekali karena konsekuensi dari segala bentuk aspek dalam bernegara ialah manusia (masyarakat). Negara dalam hal ini menempatkan manusia sebagai dasar bangunnnya, sehingga manusia diklaim sebagi asal mula dan kekuasaan negara. Manusia merupakan paradigma sentral, 
terutama dalam pembangunan negara (nasional). ${ }^{31}$ Untuk itu, manusia sebagai aspek primordial sangat memiliki pengaruh penting dalam perkembangan arus peradaban dalam suatu negara. Maka, akhlaq luhur yang ada dalam diri manusia tersebut tentu akan turut membawa negara menuju peradaban yang maju sesuai dengan moralitas al-Qur'an.

Sehingga berdasarkan analisis di atas, sila ke dua dari Pancasila ini, sangat relevan dengan rumusan Maqashid Syariah yang termasuk dalam kategori Dharuriyat dan masuk kualifikasi memelihara jiwa/manusia (Hifdz an-Nafs). Sila ini bisa dikatakan sebagai manifestasi dari nilai-nilai yang terkandung dalam alQur'an dan Hadis yang mengajarkan kepada manusia untuk menjadi manusia yang beradab atau memiliki akhlaq al-karimah. Andaikan saja sila kedua ini tidak ada, bisa saja tercipta masyarakat yang bebas lepas dalam bertindak (free action) yang berpotensi membawa mereka ke dalam degradasi moral dan kehancuran.

Begitupun juga esensi dalam sila yang berbunyi “kemanusiaan yang adil dan beradab” bukan berarti masyarakat menjadi terkungkung dalam ruang etik bernegara, namun dalam hal ini masyarakat masih memegang statusnya sebagai manusia yang merdeka atau bebas, hanya saja kebebasan yang diberikan disini bukanlah kebebasan yang tanpa batasan karena sebagai mahluk yang tinggal di dalam suatu negara yang menjunjung tinggi nilai-nilai ke'arifan lokal (local wisdom) tentunya harus mematuhi aturan-aturan yang ada selama tidak bertentangan dengan moralitas al-Qur'an.

${ }^{31}$ Kaelan, Pendidikan Pancasila, 139 
3. Persatuan Indonesia

Hakikat dari sila ke tiga ini didasari dan dijiwai oleh sila pertama (Ketuhanan) dan sila kedua (Kemanusiaan). Dengan kata lain manusia sebagai makhluk Tuhan yang Maha Esa yang harus direalisasikan pertama ialah mewujudkan suatu persatuan yang terdiri dari berbagai kelompok atau golongan dalam suatu persekutuan hidup yang disebut negara. Oleh karena itu persatuan adalah sebagai akibat adanya manusia sebagai makhluk Tuhan. Adapun hasil persatuan diantara individu-individu, pribadi-pribadi dalam suatu wilayah tertentu disebut sebagai rakyat, dan rakyat termasuk unsur pokok dalam suatu negara. Allah berfirman dalam Q.S al-Hujurat ayat 13 :

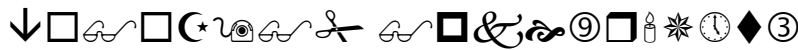

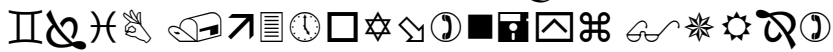

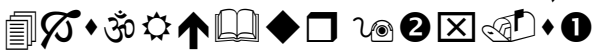

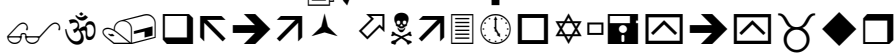

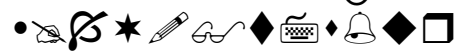

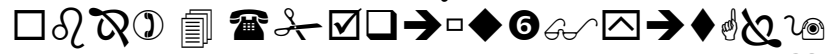

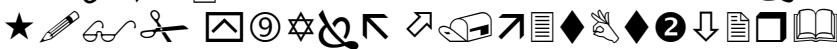

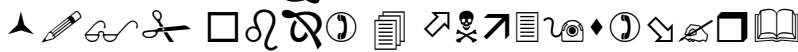

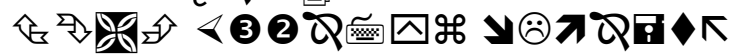

"Hai manusia, Sesungguhnya Kami menciptakan kamu dari seorang laki-laki dan seorang perempuan dan menjadikan kamu berbangsa - bangsa dan bersuku-suku supaya kamu saling kenal-mengenal. Sesungguhnya orang yang paling mulia diantara kamu disisi Allah ialah orang yang paling taqwa diantara kamu. Sesungguhnya Allah Maha mengetahui lagi Maha Mengenal."

Kemudian dalam Q.S al-Mu'minun ayat 52 :

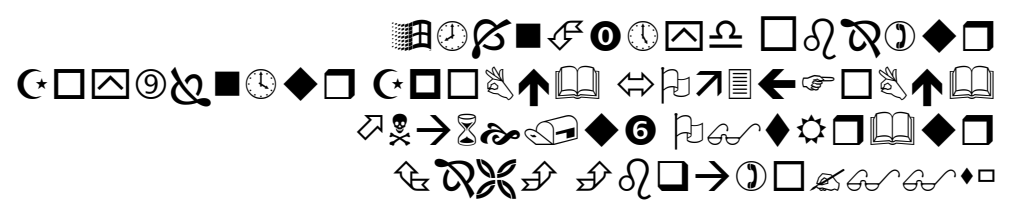


"Sesungguhnya (agama Tauhid) ini, adalah agama kamu semua, agama yang satu dan aku adalah Tuhanmu, Maka bertakwalah kepada-Ku"

Lagi, dalam Q.S al-Anfal ayat 46 :

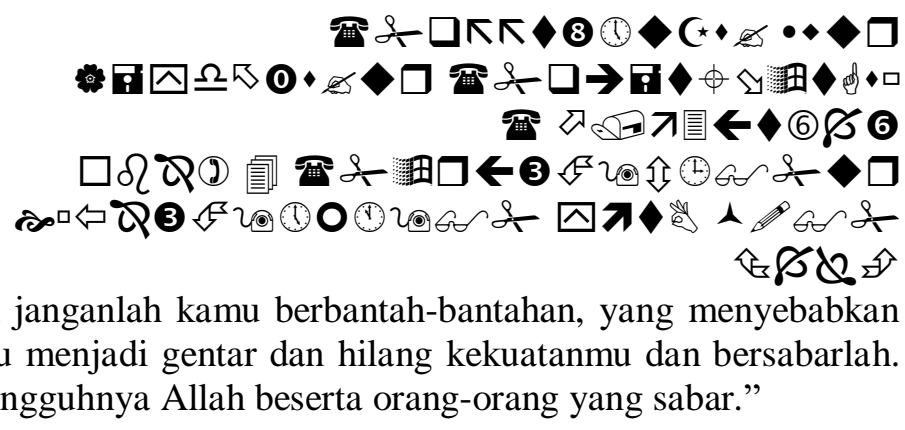

Dari ayat di atas, bisa diambil pemahaman bahwasanya Allah menciptakan manusia dengan latar belakang suku dan bangsa yang pasti berbeda. Jadi, memang harus menjadi pemahaman bagi semua bahwa pada dasarnya perbedaan merupakan suatu keniscayaan. Allah swt juga sudah menegaskan di dalam al-Qu'an terkait perbedaan dan dari berbagai perbedaan tersebut Allah mengajarkan kita untuk saling mengenal dan menyayangi, juga perbedaan bukanlah suatu alasan untuk bercerai berai dan saling mengangkat senjata untuk berperang antar bangsa, suku, golongan satu sama lain.

Pada dasarnya, beberapa gagasan muncul diseputar konsep Islam tentang komunitas (ummah). Konsep mendasarnya ialah Islam, yang artinya tunduk kepada Tuhan dan masuk dalam kesepakatan damai. Konsep ini menggambarkan hubungan yang fundamental terkait Tuhan dengan manusia. Konsep utama Islam mengungkapkan kesatuan antar elemen masyarakat yang sejatinya berbeda dan anjuran untuk tidak saling berdebat satu sama lain 
karena hal tersebut bisa mereduksi kokohnya kekuatan persatuan bangsa Indonesia.

Konsep ummah juga menggambarkan suatu masyarakat beriman yang bercorak universal. Secara teori, ummah percaya bahwa ajaran Islam merangkul seluruh dimensi kemanusiaan dan membebaskan siapa saja untuk beragama dan beribadah sesuai dengan keyakinannya. Seperti halnya ketika Rasulullah memberlakukan piagam madinah. Rasul bersedia memberikan perlindungan kepada seluruh masyarakat madinah yang memliki latar belakang sosial-kultural yang berbeda.

Dalam ranah ini juga masih sangat relevan dengan konsep Maqasid Syariah yang masuk dalam aspek Dharuriyat yang secara spesifik bertujuan untuk pemeliharaan persatuan (Hifdz al'Ummah). Karena sejatinya Allah memang ingin mendidik hambanya supaya saling mengenal, dan mengobati sehingga dari hal yang berbeda itu bisa tercipta sebuah persatuan kedalam suatu tubuh yang selanjutnya kita kenal sebagai Negara.

4. Kerakyatan yang dipimpin oleh hikmat kebijaksanaan dalam permusyawaratan/perwakilan.

Makna pokok dari sila keempat adalah kerakyatan yaitu kesesuaiannya dengan hakikat rakyat yang bersifat penjumlahan manusia-manusia, semua warga dalam satu wilayah negara tertentu. Maka dari itu hakikat rakyat adalah sebagai akibat bersatunya manusia sebagai makhluk Tuhan dalam suatu wilayah negara tertentu. Konsekuensinya dalam hidup kenegaraan itu haruslah mendasarkan pada nilai bahwa rakyat merupakan asal mula kekuasaan negara. Maka negara harus bersifat demokratis, 
hak serta kekuasaan rakyat harus dijamin baik secara individu maupun bersama. ${ }^{32}$ Allah berfirman dalam Q.S as-Syura ayat 38 :

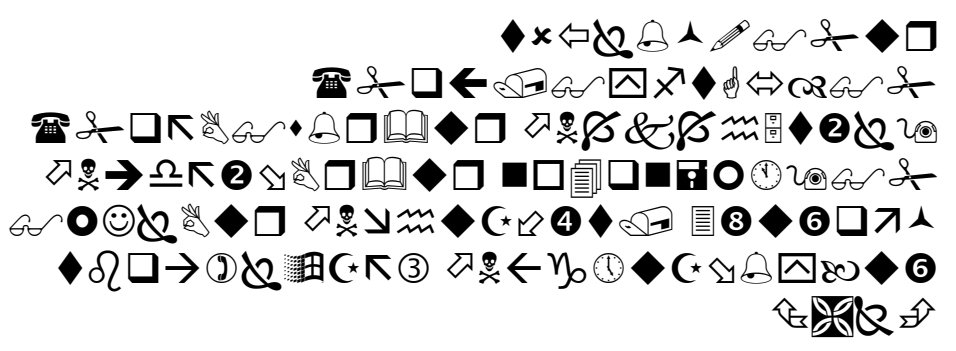

"dan (bagi) orang-orang yang menerima (mematuhi) seruan Tuhannya dan mendirikan shalat, sedang urusan mereka (diputuskan) dengan musyawarat antara mereka; dan mereka menafkahkan sebagian dari rezki yang Kami berikan kepada mereka."

Kemudian dalam Q.S Ali Imran ayat 159 :

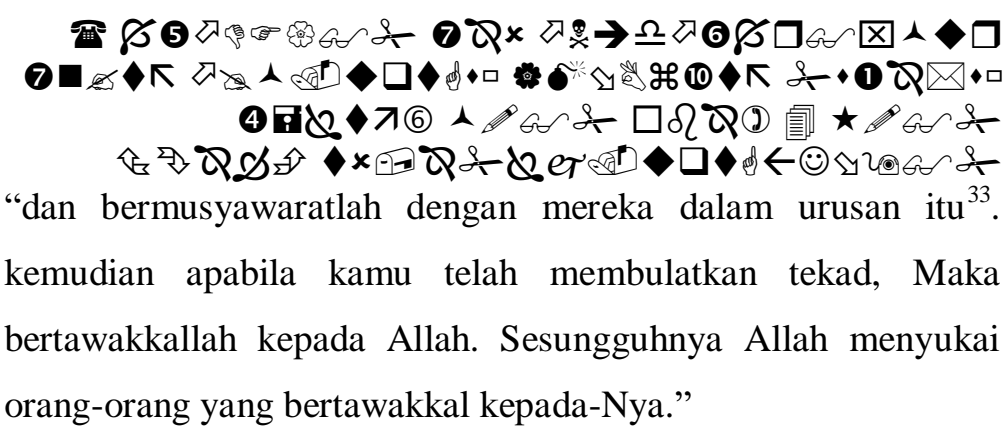

Dari hujjah di atas, bisa dipahami bahwa maqashid syariah yang terkandung didalam sila ke empat adalah bahwa hakikat manusia sebagai masyarakat Indonesia merupakan makhluk Tuhan Yang Maha Esa yang bersatu dan memiliki visi yang sama, yakni mewujudkan negara Indonesia yang maju dan bermartabat. Untuk itu, masyarakat sebagai komponen terpenting dalam suatu negara harus mendapatkan haknya

${ }^{32}$ Kaelan, Pendidikan Pancasila, 66

${ }^{33}$ Maksudnya: urusan peperangan dan hal-hal duniawiyah lainnya, seperti urusan politik, ekonomi, kemasyarakatan dan lain-lainnya. 
sebagai warga negara dan hak paling fundamental sebagai nilai filosofis dari sila kerakyatan tersebut ialah nilai demokrasi yang secara mutlak harus diimplementasikan.

Adapun aspek primordial dalam nilai demokrasi berdasarkan moralitas Islam ialah bagaimana seharusnya mengarahkan berbagai macam perbedaan ke dalam satu visi melalui musyawarah mufakat antara masyarakat dengan pemerintah. Hal yang demikian ini dimaksudkan untuk mewujudkan dan mendasarkan suatu keadilan dalam kehidupan sosial agar tercapainya tujuan bersama dalam satu negara (Indonesia). Namun, jika dengan musyawarah bersama ditemukan jalan buntu akibat dari kompleksitas permasalahan dan keadaan, maka pemerintah sebagai pemegang kekuasaan boleh memutuskan suatu perkara, dengan catatan tetap berpegang teguh pada undang-undang yang berlaku dan menjujung tinggi nilai kemanusiaan yang beradab. Jadi, dalam sila ke empat ini masih relevan dalam kategori Dharuriyat yang bisa dipahami sebagai kebutuhan primer, yakni apabila tidak diwujudkan akan mengancam keselamatan masyarakat dalam suatu negara.

5. Keadilan sosial bagi seluruh rakyat Indonesia

Sila kelima ini memiliki makna fundamental tentang keadilan, yaitu hakikat kesesuaian dengan hakikat adil. Berbeda dari sila yang lainnya maka sila kelima ini didasari dan dijiwai oleh oleh keempat sila lainnya yaitu: Ketuhanan, Kemanusiaan, Persatuan dan Kerakyatan. Hal ini mengandung hakikat makna bahwa keadilan adalah sebagai akibat adanya negara kebangsaan dari manusia-manusia yang berketuhanan yang maha esa. Sila keadilan sosial ini merupakan tujuan dari keempat sila 
sebelumnya. ${ }^{34}$ Sebagaimana Allah berfirman dalam Q.S An-Nahl ayat 90 :

र 2त है। (3) 1 की की $\square$ करष(ग)

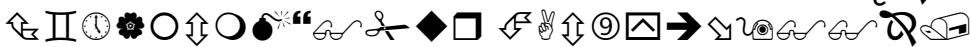

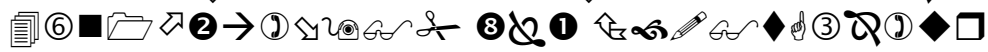

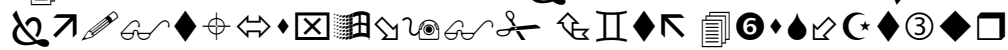

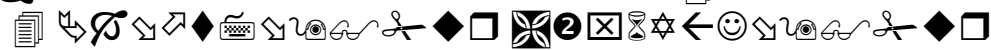

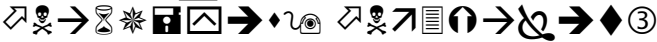

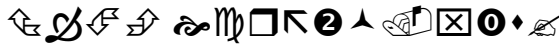

"Sesungguhnya Allah menyuruh (kamu) Berlaku adil dan berbuat kebajikan, memberi kepada kaum kerabat, dan Allah melarang dari perbuatan keji, kemungkaran dan permusuhan. Dia memberi pengajaran kepadamu agar kamu dapat mengambil pelajaran"

Kemudian dalam Q.S An-Nisa' ayat 58 :

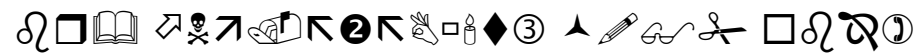

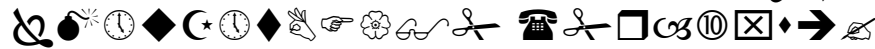

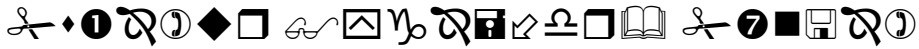

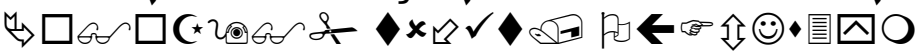
क्ष

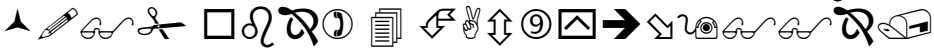

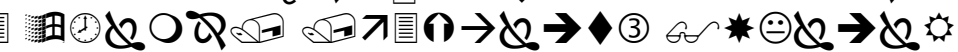

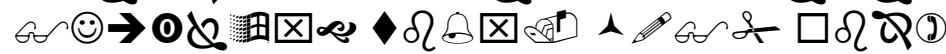

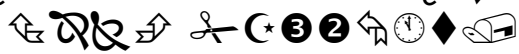
"Sesungguhnya Allah menyuruh kamu menyampaikan amanat kepada yang berhak menerimanya, dan (menyuruh kamu) apabila menetapkan hukum di antara manusia supaya kamu menetapkan dengan adil. Sesungguhnya Allah memberi pengajaran yang sebaik-baiknya kepadamu. Sesungguhnya Allah adalah Maha mendengar lagi Maha melihat"

Melihat dalil di atas, kita juga bisa mengambil pemahaman sekaligus menemukan visi-misi dari ajaran Islam yang juga menggariskan seperangkat prinsip etis yang relevan dengan sila ke

${ }^{34}$ Kaelan, Pendidikan Pancasila, 66 
lima dari pancasila sebagai sebuah acuan dalam penyelenggaraan negara. Antara lain: nilai-nilai keadilan ('adl), dan persamaan (musawa). Inilah suatu kecocokan yang sudah ditegakkan oleh komunitas politik pemerintahan dengan menyerap moralitas yang relevan dengan ajaran Islam yang mengedepankan prinsip keadilan dan persamaan tanpa memandang adanya kelas atau status sosial masyarakat sebagai warga Indonesia.

Dalam ranah ini juga masih sangat relevan dengan konsep Maqasid Syariah yang masuk dalam aspek Dharuriyat yang secara spesifik untuk pemeliharaan sosial (Hifdz al-'Ijtima). Jadi, untuk mewujudkan tujuan negara sebagai tujuan bersama, maka dalam hidup kenegaraan harus mewujudkan jaminan perlindungan bagi seluruh warga yang didasarkan suatu prinsip keadilan yang timbul dalam kehidupan bersama (kehidupan sosial). Nilai-nilai inilah yang merupakan suatu nilai dasar bagi kehidupan kenegaraan, kebangsaan dan kemasyarakatan.

\section{KESIMPULAN}

Berdasarkan uraian dalam pembahasan ini, maka dapat diambil sebuah kesimpulan sebagai berikut:

Dapat disimpulkan bahwa: (1) Dari sila pertama sampai sila ke lima dalam pancasila di atas, bisa dipahami bahwa Pancasila merupakan sebuah visi dari penyelenggaraan kehidupan berbangsan dan bernegara untuk mewujudkan kehidupan yang menjunjung tinggi nilai-nilai keTuhanan, Kemanusiaan, Persatuan, Kerakyatan serta Keadilan bagi seluruh elemen masyarakat sebagai aspek penting dalam suatu negara. Dengan melihat realitas tersebut sudah sangat jelas bahwa tidak ada satu unsur pun secara ontologis dalam Pancasila yang bertentangan dengan 
Syariat Islam. Untuk itu bisa dikatakan bahwa pancasila merupakan aktualisasi akurat dari pendidikan moralitas Islam yang bersumber dari al-Qur'an dan Hadis nabi yang sahih yang sudah disesuaikan dengan keadaan sosial-kultur masyarakat yang ada ;dan (2) Konsep maqasid alsyari'ah setelah dilakukan pengkajian perlu dikembangkan guna relevansinya terhadap Pancasila sebagai landasan filosofis Negara, serta untuk menjawab problem manusia di era modern. Dalam hal ini wacana dimasukkannya 'pemeliharaan sosial' (Hifdz al-Ijtima') dan 'pemeliharaan persatuan' (Hifdz al-'ummah) sangat urgen dan signifikan untuk dipikirkan dan diwujudkan dalam teori ushul fiqh dan filsafat hukum Islam.

\section{DAFTAR PUSTAKA}

Abdullah, Mudhofir. Masail Al-Fiqhiyyah: Isu-isu Fikih Kontemporer, cet. 1. Yogyakarta: Sukses Offset, 2011.

Al-Syatibi, al-Muwafaqat fi ushul al ahkam, Mesir: Daar Al Fikr, Jilid I, t.t.

Asmawi. Studi Hukum Islam: Dari Tekstualis-Rasionalis Sampai Kontemporer, cet. 1. Yogyakarta: Teras, 2012.

Departemen Agama R.I,al-Qur'an dan Terjemahnya, Jakarta: CV Naladana, 2004.

Effendi, Satria, Ushul Fiqih, Jakarta:Kencana, 2005.

Fazlurrahman, Islam, terj. oleh Ahsin Muhammad Bandung: Pustaka, 1984.

Haq, Hamka. Al-Syathibi: Aspek Teologis konsep Maslahah dalam Kitab almuwafaqat. Jakarta: Erlangga, 2007.

Hamid Hasan, Husein, Nazariyah al-Maslahah fi al-Fiqh al-Islảmǔ, Mesir: Dar alNahdah al-'Arabiyyah, 1971.

Imaduddin Abu Al Fida' Isma'il bin Katsir, Imam jalil al-Hafidh, Tafsir alQur'anul Karim; Ibnu Katsir, Mesir, Daar Mesr Ath Tabaah, t.t.

Jaya Bakri, Asafri, Konsep Maqashid Syari'ah Menurut al-Syatibi, Cet. I; Jakarta: PT Raja Grafindo Persada, 1996.

Kaelan. Pendidikan Pancasila. Yogyakarta: Paradigma, 2010. 
Kamali, M. Hashim, Membumikan Syariah, Terj. Shariah Law, Jakarta:Mizan Publika, 2008.

. Membumikan Syari'ah: Pergulatan Mengaktualkan Islam. Jakarta: Mizan Publika, 2013.

Prinsip dan Teori-Teori Hukum Islam:Ushul al-Fiqh. Yogyakarta: Pustaka Pelajar Offset, 1996.

Khalaf, Abdul Wahab, Ilmu Ushul Fiqih, Cet. 12; Khairo: Daar Al-Qalam, 1978.

Mardani, Ushul Fiqh, Jakarta: Raja Grafindo Persada, 2013.

Muhammad Syah, Isma'il, Filsafat Hukum Islam, Jakarta:Bumi Aksara, 1992.

Nasution, Harun, Islam Ditinjau dari Berbagai Aspeknya, Jilid II, Jakarta: UI Press, 1984.

Syarifuddin, Amir, Ushul Fiqh, Jilid 2, Cet. I; Jakarta: PT Logos Wacana Ilmu, 1999.

Warson Munawwir, Ahmad, Kamus al-Munawir, Surabaya: Pustaka Progresif, 1997. 